Siobhan Neary*

DOI: $10.18290 /$ pepsi-2019-0009

\title{
Diversifying the Careers Workforce: Opportunities and Challenges
}

\section{ABSTRACT}

Attracting high quality candidates with relevant and pertinent experience to any profession is often a challenge. A UK based research project is presented that employs a protean lens to examine the motivations and expectations of career changers who have recently moved into the field of career guidance and counselling. The research comprised of a mixed methods design, utilising an online self-completed survey and interviews aimed at practitioners who have transitioned into the careers field over the last five years. The data reflects practitioners working in a range of settings including, schools, further education colleges and higher education. The initial findings present several important issues for the careers field in the UK which may have wider applicability. Respondents transitioned from a diverse range of professional backgrounds including HR, education management consultancy and research. A common motivation focused on supporting and influencing a social justice agenda. The research identifies that the field is successful in recruiting highly qualified and experienced candidates, the challenge is about diversity and attracting a workforce that better reflects the populace.

KEYWORDS: careers workforce, guidance, practitioners, diversity, workforce.

* Correspondence regarding the paper should be sent to: Siobhan Neary, International Centre for Guidance Studies (iCeGS), University of Derby, Derby (UK), email: s.neary@derby.ac.uk 
Navigating and understanding the increasing range of educational, vocational, academic and career options that are available to individuals has become progressively complex. The expansion of choice together with agency present considerable opportunities for individuals at all ages and stages of life. The desire for certainty can result in indecision and can impact individuals' progress (Houston \& Cunnigham, 2018). De Botton (2009) challenges that adults spend their lives working in jobs chosen for them by their unthinking sixteen-year-old selves. Necessarily, the support individuals' access to enable them to understand their choices and to make informed decisions is crucial to healthy life and career progression. There is a nascent body of literature which explores the professionalization, training, competence and emerging professional identity of careers professionals (European Centre for the Development of Vocational Training [Cedefop], 2009; Neary, 2014; Hooley, Johnson, \& Neary, 2016; Gough, 2017) but there is little which explores who these practitioners are, their motivations and what they bring to the profession.

This paper aims to foreground a better understanding of the professionals who work in support careers in the UK. It responds to the call by Weber, Katsarov, Cohen-Scali, Mulvey, Nota, Rossier, J. and Thomsen (2018) for more research concerning the people who support career interventions to better understand their values, competencies, and how they perceive themselves as career professionals. This nascent research area aims to qualify the professional nature of careers work through examining the motivations, values and identity of those choosing to become career practitioners. This project, recently undertaken in the UK explores the motivations and expectations of individuals who have lately changed their career and have transitioned into the careers field. It uses the concept of a protean career as a framework for the study, specifically the emphasis on values and psychological success (Hall, 2004). This concept (Hall, 1996) adopts the change-shaping metaphor of the Greek God Protean and describes individuals 
able to repurpose knowledge, skills and abilities within the work environment: 'Protean careerists are flexible, value freedom, believe in continuous learning and seek intrinsic rewards for work' (Sullivan \& Baruch, 2009, p. 1529).

This research presents a window into how new practitioners perceive the opportunities and challenges within their career. Drawing on views of practitioners from a range of roles in the careers field, it explores the meta-competencies of self-awareness and adaptability (Hall, 2004) that they exhibit in their new roles. The research raises important questions as to the lack of diversity in recruiting careers professionals and the extent to which the perception of careers work as 'a female profession' is undermining its value to society.

\section{UNDERSTANDING CAREER CHANGE}

Individuals choose to change career for many reasons, the factors which contribute to the decision may be individual or organisational (Rhodes \& Doering, 1983), voluntary or enforced. Central to the decision is agency and the extent to which individuals control the changes they make. It has also been argued that when career transitions are embarked upon out of choice, they are driven by personal agency and represent career adaptability, as opposed to forced involuntary transitions (Damle, 2015). Haasler and Barabasch (2015) note that mid-career changes may reflect increased self-awareness and personal agency, internal struggles, a need to fully express the inner self and a move against previous restrictions and constraints. Carless and Arnup (2011) found that personality characteristics (openness to experience, extraversion), demographics (age, gender, education level and occupation tenure) and the organisational factor of job security are all determinants of a mid-career change. 
La Pointe (2013) contends that contemporary careers epitomise increased mobility, individual agency and decreased job security which are explored within theoretical perspectives such as the boundaryless career (Arthur \& Rousseau, 1996) and protean career (Hall, 1996). Movement across roles, professions and sectors, (boundaryless careers), requires individual recognition of transferable skills which in turn provide a significant advantage in changing career (Brown, Bimrose, Barnes, \& Hughes, 2012). While protean career has a greater focus on values and self-direction, both perspectives have attracted criticism (La Pointe, 2013) for over emphasising individual agency. Yet, enacting a career change requires significant agency as well as resilience. Research from Bimrose and Hearne (2012) indicate that supporting individuals to develop resilience and to be able to deal with multiple transitions is a primary element of modern career practice. Neary and Hanson (2019) suggest that new practitioners who have migrated into the careers field may have a credible empathy with clients as they have also a recently experienced transition.

\section{METHOD}

The study focused on exploring the transition of recent careers practitioners through examining their motivation for wanting to move into the field and their expectations of their new career. The skills that practitioners brought from previous careers were examined to explore their transition and the influence of internal values and self-direction in selecting their choice of new career. The research used a mixed methods design, utilising an online self-completed survey, which attracted 453 respondents. The survey's construction was informed by the review of the literature and used a combination of open comments and Likert scale questions. These focused on demographic data and explored respondent views on what attracted them to the profession, the 
skills and experience they felt were transferable, satisfaction with their new career and future career progression. Additionally, ten semi-structured interviews provided a personally constructed narrative of the experience. The survey was distributed using professional associations and using a snowball approach. It was aimed at practitioners who had transitioned into the field during the last five years.

The survey attracted responses from practitioners working in the higher education, secondary schools (aged 11-18) and further education colleges offering post- 16 academic and vocational programmes. The majority of respondents (77\%) were female, $94 \%$ defined themselves as ethnically white, $65 \%$ were aged 45 or older and $68 \%$ had a postgraduate qualification as their highest award. $89 \%$ of practitioners had a relevant qualification in career guidance, counselling or coaching. An abductive approach was used for data analysis, which resulted in descriptive statistics generated through SPSS and thematic analysis informed by Braun and Clarke (2006).

Although this was a purposive sample, it was sufficiently large to enable us to make some observations about the field and the views of the new practitioners within it. The average length of time respondents had been in their new career was just over 5 years which would provide sufficient time for transition and establishment in the new career and with distance enable reflection on the transitionary experience.

\section{FINDINGS}

\section{Transferability of skills}

New practitioners came from a broad range of occupational areas. Just over $30 \%$ of the respondents came from HR, training, learning and development or a school background, which is to be expected. However, the field is attracting individuals from vari- 
ous career backgrounds including banking, communications and marketing, third sector, social work, consultancy, manufacturing, TV production, medicine and health care. The overwhelming majority of respondents had significant work experience in other sectors before entering the careers profession. Respondents identified having worked an average of thirteen years in other sectors before moving into the career field, however many changed career within the first ten years. $18 \%$ of the respondents worked for over 20 years before their career change; this was often an enforced change as a result of redundancy.

When asked to analyse the skills and knowledge they had developed in their previous career, practitioners were able to list an extensive range of abilities.

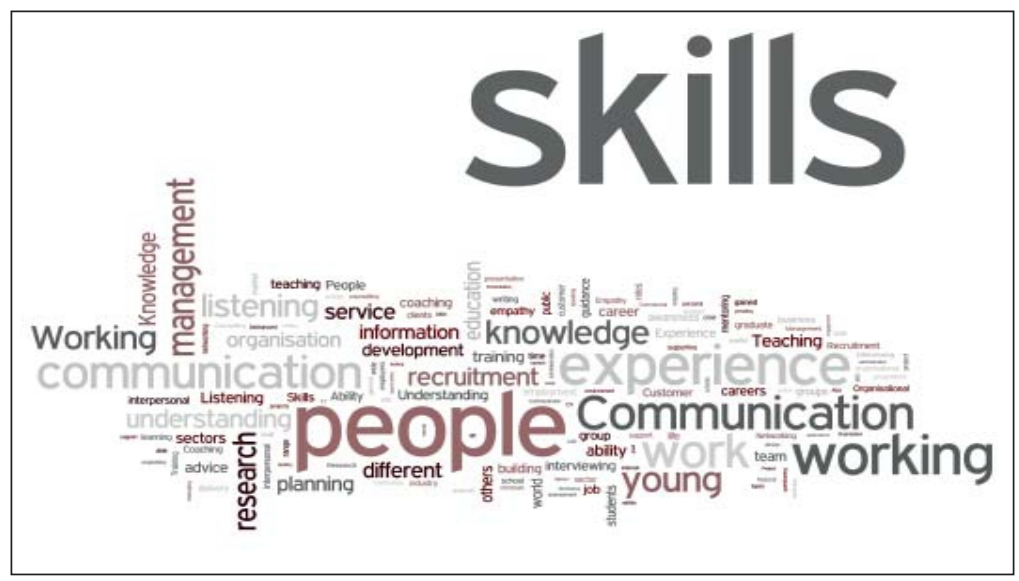

Figure 1. Range of skills pertinent to careers work were identified: communication and people skills, listening, empathy, coaching and mentoring feature.

As we can see from Figure 1, a range of skills pertinent to career work were identified: communication and people skills, listening, empathy, coaching and mentoring feature. Knowledge derived from previous relevant work experience was perceived 
as useful, whether that be commercial awareness/labour market intelligence/information or knowledge of academic and teaching environments. Other skills mentioned were research skills, negotiation and teaching. Participants were able to clearly identify and synthesise the relevancy from their previous careers to their new roles and apply this within the new context.

One interviewee articulated it as 'I feel a little like a GP - you know a little about a lot'. These findings align with those of Patton (2002) who found that decision-making, organisation and timemanagement skills are required in addition to those of counselling to be effective in career practice. The opportunity to repurpose these skills was an important element in choosing the career. This suggests an alignment with some of the principles of the protean careerist who is able to examine and package their knowledge and skills be transferable within a new context.

Knowledge and experience of recruitment processes and best practice for applications from the recruiter's perspective. Knowledge of employment law giving advice around personal and potentially sensitive topics. Ability to train/facilitate group activities (once a HR assistant, now a higher education careers consultant).

\section{Motivation for the field}

The respondents identified their motivation was strongly informed by their values and a commitment to social justice, terms such as 'help', 'assist', 'support', 'enable', 'making a difference'. Emotive language was used to describe their relationship with the role: 'passion', 'meaningful', 'helping', 'being authentic', 'rewarding', and 'making a difference'. Social justice is more than just helping people it aims to bring about a fairer society (Hooley \& Sultana, 2016). Hall refers to this as a 'Path with a Heart' (2004, p. 9) where individuals see the application of their values as serving the community or even a calling. Wanting to contribute to making a difference for young people in particular was a primary driver 
for selection of the careers field for a new career. Practitioners wanted to work with young people/people, acting as a guide, providing advice, coaching, educating people and helping them to progress in life. Regardless of which part of the careers field practitioners worked in i.e. schools, higher education, further education, there was a common synergy in terms of motivation for the role.

The opportunity to use professional specialist skills to help young people potentially change their future path (once a strategic volunteering manager, now a self-employed schools career adviser).

These findings support those of Bimrose and Hearne (2012) whose respondents reported they were anxious to make a positive difference. The comments from respondents also lend weight to Haasler and Barabasch's (2015) argument that mid-career changes reflect increased self-awareness and personal agency. The opportunity to change career either as a forced or unforced decision reflects Manierio and Sullivan (2006) work on the kaleidoscope theory, where mid-career women are starting to seek balance and authenticity in terms of not allowing career to dominate their lives but to attain a greater sense being true to themselves.

Working with people and my own motivation for people to pursue meaningful work and life lives that are happy and satisfying (once a university researcher, now a higher education postgraduate internship coordinator).

\section{Meeting expectations}

When considering their expectations prior to moving into the career development sector, $74 \%$ of the respondents said that their expectations had been met and, in some instances, exceeded. However, many were not prepared for the complexity of the role 
and the amount and level of work required. The role was perceived as much more varied than was expected, for example the expectation to produce content for publications, event management, and marketing and communication activities. For those working in higher education, the level of consultancy working with academics was not originally envisaged as part of the role and the role was more corporate in terms of representing an organisation than was expected. The expectations were often contextual with practitioners working in higher education having different expectations from those working in schools for example. The amount of administration was generally an issue for many.

I have already been able to make a difference and working with students is very rewarding (once a HR professional, now an employability education projects officer).

Yes \& No - less face to face student time \& more planning \& organisation (once worked in advertising, marketing and communications at a blue chip company, now a higher education careers consultant).

For many neo-liberal issues related to managerialism and bureaucracy tended to detract from the client focused activities. For most, it was the client focus that attracted them in to the profession and the demands of working in target or contract driven environments is perceived as undermining the quality and professionalism of the services being provided. This tension between the contractual needs of the organisation and the client is starting to impact in some parts of the sector with practitioners leaving the field (Neary \& Priestley, 2018).

The core role does meet the expectations, but the organisation has become obsessed with overly complex recording of interventions, 
targets and seems to want to measure everything (once a sixthform administrator, now a school careers adviser).

Of those who responded less positively, the main reasons in addition to bureaucratic requirements were salary, progression and professional esteem. The issues concerning salary and progression appeared to be context related, with this being less of an issue in higher education than for practitioners working in schools and the adult sector. As much of the careers provision in England is publicly funded, the impact of 'austerity' measures as well as policy have contributed to a significant reduction in funding available in recent years (Hooley, Matheson, \& Watts, 2014). This has resulted in lower wages, lack of job security, limited budgets for development and even initial training. This is starting to have a severe impact on employers' ability to recruit (Neary \& Priestley, 2018).

Funding cuts have reduced the opportunities to work in development roles in the sector and job security has become more of an issue (once worked in electronic component sales, now an employer services manager in higher education).

Within certain parts of the field, particularly those working with young people and adults pay was perceived as low and there were few opportunities for advancement, 51\% stated that they did not feel there was real opportunity for progression, except for management. Higher education and the private sector were perceived as providing greater opportunity for career progression opportunities, with practitioners in these parts of the field being provided with opportunities to extend their qualifications, specialist knowledge and develop new skills such as using psychometric testing tools. This suggests that the sector is highly qualified with $68 \%$ having a post graduate qualification, which is many instances is the higher level training course for the field, yet the traditional 
opportunities for career progression are limited. Arguably it could be claimed that the skills, knowledge and expertise of many of those in the profession are not being fully maximised or rewarded.

\section{The demographics of the workforce}

One of the issues identified through the research by both the respondents and the researchers was a concern about the homogeneity of the workforce which is predominantly female, white and aging. One respondent defined the profession as being perceived as 'a bunch of nice ladies in cardigans who sit students down for a lovely wee chat about their futures'. This presents a worrying picture of the workforce in the UK, which may or may not reflect other countries experiences. The gender breakdown identified in this research ( $77 \%$ female) presents some interesting questions for the sector, not least of which is does this female domination influence the poor salaries identified earlier? Additionally, how being perceived as a female-dominated profession affects status, recruitment and ability to represent the needs of the client group from a social justice perspective.

We need to raise the profile of career sector as it is portrayed as boring middle class white women who want to do good to those who are less fortunate (once an employment and education manager, now a private careers consultant).

There is a real need to recruit a diverse cross section of people, of varying ages, into career guidance, it's critical (once a market researcher, now a local government personal adviser).

\section{DISCUSSION}

The data presents that the careers workforce in the UK is attracting highly qualified, highly skilled individuals making a choice to 
work in the careers field and want to make a difference to people's lives and (their career progression). $89 \%$ of the practitioners have a professional qualification reflecting a strong engagement with professional training within the field. The principles of the protean career are exemplified in the values espoused by those entering the profession. This suggests an orientation to protean/transformational career in demonstrating being highly values driven with a high-self direction (Hall, 2004). The field is attracting people who are committed to and passionate about their new career. This is a testament to the profession and the extent to which highly experienced career changers perceive it as a new career which reflects their value system. For many the lack of perceived progression opportunities, other than management, limits the field as a profession and opportunities need to be explored that clearly identify career opportunities. For many on-going professional development focused on use of new tools, higher level qualifications and project management. This begs an interesting question concerning the career trajectories of client focused practitioners. There was some evidence from the research which suggested practitioners moved into and through different parts of the sector i.e. from school to HE, however this was related to seeking higher pay and job security. For this reason higher education was particularly attractive due to the focus on employability for graduates there has been a significant increase in staffing over recent years (Neary \& Hanson, 2019).

The homogeneity of the workforce could be perceived as a barrier to recruitment. This has been an issue identified by employers within the field who are concerned about age particularly and the lack of young people wanting to enter the profession. When considering diversity in the workplace Parker and Roan (2015) refer to the need to achieve a critical mass which defines the quantity required to start a chain reaction which would represent a more diverse profession in terms of age, gender and ethnicity. It would be interesting to consider what a critical mass would look like 
in terms of careers professionals. Disability is also an area that needs to be addressed but there is not the space to explore this to an acceptable level here. Diversification of the workforce is important issue for three key reasons; firstly, the research identified the workforce does not reflect the range and diversity of clients' practitioners are working with. In terms of ethnicity the representation in the workforce better reflects national census data which indicate in the $201180.5 \%$ of the population defined themselves as white British (Office of National Statistics, 2011). Strategies need to be introduced by careers employers and the professional association to encourage, through recruitment practice, a more representative workforce. The introduction of the apprenticeship model in the UK may act as driver to make training more accessible as apprenticeships are all employed. An apprenticeship in career development is likely to be available during 2019. As such regardless of how highly skilled and experienced practitioners are, having a workforce that reflects the cultural, age and gender makeup of the population will offer a greater sense of representation and role modelling. McMahon, Watson and Bimrose (2015) posit that the internationalisation of the career profession requires consideration to ensure cultural and contextual resonance.

Secondly, the field like many other parts of the working world has an aging workforce, this is not unusual, but it is potentially impacting on employers within the sector. Recent research in the UK by the Professional Association, the Career Development Institute (Neary \& Priestley, 2018) presents employers in the UK have real concerns about the retirement of highly knowledgeable and experienced staff. The data suggests that many of those entering the profession are doing so as a second plus career, as such practitioners are bringing in a wealth of experience but the sector is potentially missing out on benefits that younger people may bring to the work force including aiding staff retention, technological knowledge and succession planning (Hasluck, 2012). 
Finally, there is much comment within this research and Neary (2018) concerning poor salaries across the sector, some parts are worse than others. The low salary combined with a predominantly female workforce suggests that gender as well as public funding issues may have an influence on salary and conditions of service. Allan and Moffett (2015) align the career guidance field with many of the 'new professions' which are frequently female dominated. Additionally, Grönlund and Magnusson (2013) identify that the percentage gender wage gap is related to the percentage of females in the profession. The impact of lower salaries may be one of the determinants which is discouraging a wider range of applicants. There is a recognised tension between the promotion of postgraduate level training for practitioners with salaries and progression which is not at an equivalent level. This therefore challenges the professional status of the occupation.

\section{CONCLUSIONS}

The messages are promising for the careers field in terms of being able to recruit experienced, skilled and highly qualified practitioners. The challenge is that recruitment needs to be more representative of the people careers practitioners work with; progression opportunities need to be addressed as does practitioners' salaries. The study has suggested that practitioners demonstrate protean career principles in choosing a career which reflects their value system and which they can be self-directed. Practitioners generally felt that their new role matched their expectations, those that didn't were challenged by competing managerialist agendas. This study provides a fascinating window into what the perceptions of recent entrants into career guidance and counselling practice in the UK and what they think about their profession. It specifically draws attention to the many positive aspects about the career in addition to some of the challenges, specifically the 
lack of funding. It is an important study which challenges the profession to consider how it seeks to ensure that the workforce is more representative of the diverse society that it supports and remains an attractive career for those with suitable skills, experiences and motivations. McMahon et al. (2015) challenges us to raise the profile of careers practice to be visible, sought after, credible, ethical, cultural and contextually resonant. It is time we all took up this challenge.

\section{REFERENCES}

Allan, G., \& Moffett, J. (2015). Professionalism in career guidance and counselling - how professional do trainee career practitioners feel at the end of a postgraduate programme of study. British Journal of Guidance and Counselling, 44(4), 447-465.

Arthur, M.B., \& Rousseau, D.M. (Eds.) (1996). The Boundaryless Career. A New Employment principle for a new organisational era. New York, NY: Oxford University Press.

Bimrose, J., \& Hearne, L. (2012). Resilience and career adaptability: Qualitative studies of adult career counselling. Journal of Vocational Behavior, 81(3), 338-344.

Braun, V., \& Clarke, V. (2006). Using thematic analysis in psychology. Qualitative Research in Psychology, 3(2), 77-101.

Brown, A., Bimrose, J., Barnes, S.A., \& Hughes, D. (2012). The role of career adaptabilities for mid-career changers. Journal of Vocational Behavior, 80(3), 754-761.

Carless, S., \& Arnup, J. (2011). A longitudinal study of the determinants and outcomes of career change. Journal of Vocational Behaviour, 78(1), 80-91.

Cedefop. (2009). Professionalising career guidance. Thessaloniki, Greece: European Centre for the Development of Vocational Training.

Damle, P. (2015). Tracing the tangential career transition. Journal of Management Research, 15(2), 111-122.

De Botton, A. (2009). The pleasures and sorrows of work. London, England: Hamish Hamilton.

Gough, J.P. (2017). Educating career guidance practitioners in the twenty-first century. British Journal of Guidance and Counselling, 45(2), 199-207. 
Grönlund, A., \& Magnusson, C. (2013). Devaluation, crowding or skill specificity? Exploring the mechanisms behind lower wages in female professions. Social Science Research, 42(4), 1006-1017.

Haasler, S.R., \& Barabasch, A. (2015). The role of learning and career guidance for managing mid-career transitions - comparing Germany and Denmark. British Journal of Guidance \& Counselling, 43(3), 306-322.

Hall, D.T. (1996). Protean careers in the 21st century. Academy of Management Executive,10(4), 8-16.

Hall, D.T. (2004). The protean career: A quarter-century journey. Journal of Vocational Behaviour, 65(1), 1-13.

Hasluck, C. (2012). Why business should recruit young people (Briefing paper). Wath upon Dearne, England: UK Commission for Employment and Skills.

Hooley, T., Matheson, J., \& Watts, A.G. (2014). Advancing Ambition: The role of career guidance in supporting social mobility. London, England: Sutton Trust.

Hooley, T., Johnson, C., \& Neary, S. (2016). Professionalism in careers. Careers England and Career Development Institute.

Hooley, T., \& Sultana, R. (2016). Career guidance for social justice. Journal of the National Institute for Career Education and Counselling, 36, 2-11.

Houston, K., \& Cunningham, E. (2018). Waiting for a career epiphany, a barrier to career decision-making. Journal of the National Institute for Career Education and Counselling, 40, 25-32.

La Pointe, K. (2013). Heroic career changers? Gendered identity work in career transitions. Gender, Work and Organisation, 20(2), 133-146.

Mainiero, L.A., \& Sullivan, S.E. (2006). The Opt out revolution: Why people are leaving companies to create kaleidoscope careers. Mountain View, CA: Davies-Black.

McMahon, M., Watson, M., \& Bimrose, J. (2015). Implications for Career Practice. In J. Bimrose, M. McMahon, \& M. Watson, Women's career development throughout the lifespan. Abingdon, England: Routledge.

Neary, S. (2014). Reclaiming professional identity through postgraduate professional development: Career practitioner reclaiming their professional selves. British Journal of Guidance and Counselling, 42(2), 199-210.

Neary, S., \& Hanson, J. (2019). A new career in higher education careers work. In C. Burke \& F. Christie (Eds.), Graduate Careers in Context, research, policy and practice. Abingdon, England: Routledge.

Neary, S., \& Priestley, P. (2018). Workforce needs of the career development sector in the UK. Stourbridge, England: Career Development Institute.

Office of National Statistics. (2011). Ethnicity and national identity in England and Wales. Retrieved August 14, 2018, from https://www.ons.gov.uk/ 
peoplepopulationandcommunity/culturalidentity/ethnicity/articles/ethnicityandnationalidentityinenglandandwales/2012-12-11

Parker, P., \& Roan, A. (2015). Organisational Perspectives. In J. Bimrose, M. McMahon, \& M. Watson (Eds), Women's career development throughout the lifespan. Abingdon, England: Routledge.

Patton, W. (2002). Training for Career Development Professionals: Responding to Supply and Demand in the Next Decade. Australian Journal of Career Development, 11(3), 56-62.

Rhodes, S.R., \& Doering, M. (1983). An integrated model of career change. Academy of Management Review, (8)4, 631-639.

Sullivan, S., \& Baruch, Y. (2009). Advances in career theory and research: A critical review and agenda for future exploration. Journal of Management, 35(6), 1542-1571.

Weber, P. C., Katsarov, J., Cohen-Scali, V., Mulvey, R., Nota, L., Rossier, J., \& Thomsen, R. (2018). European Research Agenda for Career Guidance and Counselling. In V. Cohen-Scali, J. Rossier, \& L. Nota (Eds.), New Perspectives on Career Counseling and Guidance in Europe (pp. 219-250). Berlin: Springer. 